УДК 342.7

\author{
H. В. Марущак

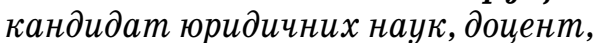 \\ доцент кафедри теорії та історії держави і права, конституиійного права \\ Чернігівського національного технологічного університету
}

\title{
ЩОДО ПОЛІТИЧНОГО АСПЕКТУ ПРАВ ЛЮДИНИ
}

Міжнародно-правові акти про права людини розглядають державу як основний інструмент забезпечення цих прав і закріплюють за нею відповідні зобов'язання. Виступаючи як організована політична влада, держава володіє величезними потенційними можливостями спрямовувати вплив на всі сфери життя суспільства. У статті 3 Конституції України закріплюється, що «права і свободи людини та їх гарантії визначають зміст і спрямованість діяльності держави. Держава відповідає перед людиною за свою діяльність. Утвердження і забезпечення прав і свобод людини є головним обов'язком держави» [1].

Проблема взаємин держави та індивіда завжди була і продовжує перебувати в числі найважливіших проблем науково-правової думки. Вона має багатовікову історію, і якою би не була держава за своєю сутністю, «який би режим у ній не панував взаємини між людиною і державою завжди являли інтерес не тільки теоретичний, релігійний, філософський, але і прикладний, оскільки без урахування цієї взаємодії, неможливо встановити в суспільстві порядок, необхідний для панівної еліти і для демократично обраних правителів» [2, с. 214].

Під час пошуку моделей взаємин держави 3 особою головні труднощі завжди полягають у встановленні такої системи і порядку, за яких особа мала би можливість безперешкодно розвивати свій потенціал (здібності, талант, інтелект) і загальнодержавні цілі (те, що об'єднує всіх) визнавалися б і шанувалися. Подібний баланс якраз і отримує своє вираження в правах, свободах і обов'язках людини [3, с. 13].

Окремі аспекти цієї проблеми розглядалися в працях М. Вітрука, О. Лукашевої, О. Кучинської, П. Лупінської, С. Любичева, М. Малеїна, Т. Москалькової, В. Нора, В. Погорілка, І. Петрухіна, Ф. Рудинського, В. Тихого, Ю. Тодики, Н. Шукліної та інших авторів. Вони внесли низку пропозицій щодо подальшого вдосконалення правового статусу людини, захисту прав і свобод особи. Однак наявність численних наукових доробків у цій сфері не зменшуе актуальності подальших досліджень змісту суті прав людини.

Метою цієї статті є аналіз прав людини як політико-правової категорії, розгляд наукових підходів до проблеми співвідношення інтересів особи і держави, роль держави в додержанні прав і свобод людини та перспективи їх розвитку в сучасному суспільстві.
Права людини, як частина природи їх носія індивіда, розглядалися і розглядаються у нерозривному зв'язку із проблемами влади, демократії, соціальних та політичних інститутів. Так, Ф.М. Рудинський визначив права людини як: можливості людини в її самореалізації та розвитку, які виникають (існують) завдячуючи власним здібностям (стану) індивіда та (або) у результаті його підтримки $з$ боку держави та суспільства [4, с. 141]. Білоруські вчені визначають права людини як соціально і морально обгрунтовані і підтримані правом вимоги окремих індивідів або соціальних груп до суспільства і держави на підставі їхньої приналежності до людства з метою забезпечення вільного, всебічного розвитку особистості [5, с. 12]. О.Г. Бережнов вважає, що права людини - це «певний мінімум загальносоціальних (у рамках окремого суспільства), загальнолюдських і загальнодемократичних вимог до правового і соціального становища кожної особистості, реалізація яких має і може бути забезпечена в будь-якому суспільстві, незалежно від особливостей його соціально-правової системи» [6, с. 173]. О. Хеффе називає права людини «справедливими претензіями людей стосовно один одного, а потім і стосовно держави» [7, с. 248].

Визначення прав людини аргументовані в роботах О.А. Лукашевої. Вони пояснюються нею як «гарантована законом і забезпечена судовим захистом здатність реалізувати свої домагання в різних сферах життедіяльності...» [8, с. 2]. Н.Г. Шукліна пропонує такий варіант дефініції: права людини це досягнуті у ході історичного розвитку людської цивілізації можливості особи задовольняти свої життєво важливі потреби та інтереси, зафіксовані у міжнародних документах і національних нормативно-правових актах, і через це гарантовані та стимульовані з боку міжнародної спільноти, відповідного суспільства і держави [9, с. 67].

Виходячи з цього, права людини - це можливості особистості задовольняти і розвивати свої потреби і інтереси, насамперед гарантовані державою. I це справді так. Категорія прав людини діє виключно у стосунках між людиною і владою. Права людини - це межі влади. Вони визначають ту сферу життєдіяльності людини, в яку влада (держава) не може втручатись і ті обов'язки, які має держава щодо людини [10].

О.А. Лукашева слушно зазначає, що права людини фіксують і висловлюють систему 
життєзабезпечення особистості, без якої неможливим $€$ їі нормальний розвиток. Цінність прав людини полягає в тому, що в них закладені ті принципи взаємодії людини і суспільства, які забезпечують нормальну життєдіяльність того чи іншого [11, с. 55].

Ціннісний характер прав людини надає усвідомлення вимог індивіда i опосередкування їх волею держави, соціальної групи й особи. В ідеалі права людини покликані виразити єдність вимог людини та об’єктивних умов їх здійснення. У цьому відбивається зацікавленість держави у всебічному розвитку своїх громадян.

Цінність особистих прав і свобод громадян полягає в тому, що людина виступає як первинний елемент суспільства, що самоорганізується і саморозвивається. Самореалізація індивіда тим ефективніше, чим більше визнається за ним прав і свобод у політичній, соціальній, культурній та інших сферах життя, що забезпечує рівень необхідного різноманіття для повноцінного розвитку соціуму. Безумовним позитивним наслідком цих процесів можна назвати правове визнання людини та їі життя в Україні як глобальної цінності. Не можна не погодитись з думкою про те, що найважливіша роль у здійсненні прав і свобод належить громадянину, який, сприймаючи норми права, усвідомлюючи їх як безумовну цінність, сприяє функціонуванню механізму правореалізації [12, с. 25].

Права людини - політико-правове явище. Як система динамічна, особисті права і свободи характеризуються здатністю до розгортання в часі і збагаченню внутрішнього змісту своїх сутнісних властивостей, а також їх соціальною спрямованістю. Згодом змінюється ціннісний зміст прав людини, крім того, вони змінюють своє положення в ієрархії правових цінностей. Зазвичай розвиток змістовних характеристик призводить до підвищення статусу прав людини, переводить їх у розряд «позачасових», «загальнолюдських» цінностей.

Центральною проблемою сучасного суспільства є вироблення і забезпечення нових юридичних норм у сфері прав людини. Нині фактично виник справжній культ прав людини, що зумовлено і кардинальною зміною загальної картини світу, тому у разі затвердження невід'ємності та універсального характеру прав і свобод людини все-таки допускається часткова модифікація їх змісту, що виходить від держави.

Міжнародні документи другої половини XX ст., ратифіковані великою кількістю держав, затвердили «права людини» як ідеал, якого інтернаціональне співтовариство має досягти. Наприклад, у ст. 1 Загальної декларації прав людини проголошується: «Усі люди народжуються вільними і рівними у своїй гідності і правах. Вони наділені розумом і совістю і мають діяти стосовно один до одного в дусі братерства» [13, с. 19].
Ідея «поваги до властивої людській особі гідності, властивої всім членам людської сім'ї, та рівних і невід'ємних прав» міститься і в низці інших документів універсального характеру. Вона згадується, наприклад, у ст. 2 Міжнародного пакту про громадянські і політичні права: «Кожна держава, яка бере участь у цьому Пакті, зобов'язується поважати і забезпечувати всім особам, що перебувають у межах її території та під її юрисдикцією, права, визнані в цьому Пакті, без будь-якої різниці щодо раси, кольору шкіри, статі, мови, релігії, політичних чи інших переконань, національного чи соціального походження, майнового стану, народження чи іншої обставини» [13, с. 41]. Правовою кульмінацією ідеї людських прав є принцип 7 Заключного акта Наради з безпеки й співробітництва в Європі 1975 р., де стверджується, що держави будуть сприяти ефективному здійсненню людських прав і свобод [14, с. 641].

На нашу думку, варто погодитися з М.В. Вітруком, який зазначив, що під правами людини в міжнародно-правовій інтерпретації розуміються основні фундаментальні права, які носять універсальний, загальний характер (поширюються на всіх, хто належить до біологічного виду homo sapiens) i які є егалітарними (всі рівноправні), системно забезпечують гідне життя і розвиток особистості в умовах досягнень сучасного суспільно-історичного прогресу [15, с. 30-31].

Суспільний прогрес, на нашу думку, безпосередньо пов'язаний 3 конкретизацією і розширенням каталогу основних прав і свобод людини, визнанням, забезпеченням на державному рівні, організацією міжнародного контролю за їх дотриманням та захистом. Національні системи, здійснюючи пошук оптимальних моделей закріплення прав та свобод людини, стали звертатися до міжнародної практики, тобто національні правові системи фіксують не тільки власні напрацювання у справі захисту прав людини, а й широко використовують нормативний і доктринальний позитивний досвід світової спільноти та зарубіжних країн.

Розглядаючи зазначену проблему про права і свободи людини, неможливо обійти дискусійне питання взаємозв'язку держави, їі інститутів і прав людини. Ліберальні теорії підкреслюють, що природні права людини існують незалежно від держави, яка несе в собі загрозу правам і свободам особистості, при цьому головне завдання - захистити людину від агресії з боку держави. Водночас, як слушно зазначив В.Д. Зорькін, «людина істота правова і, відповідно, державна» [16, с. 27].

Права людини як універсальна цінність визначають межі свободи політики, політиків та державної влади. Права людини окреслюють межі діяльності держави, визначають спрямованість державної політики. Права встановлюють чіткі правила, на яких будуються взаємини між особою 
i державою, розвиваються принципи автономіі або співпраці, взаємної відповідальності. «Проблема співвідношення прав людини і політики це питання про характер політичного режиму, суть якого визначається тим, визнає чи не визнає він панування у суспільстві правових засад, прав людини" [17, с. 237]. Як зазначила Н.Г. Шукліна, «будучи невід'ємним елементом політичного життя, вони, з одного боку, є засобом протистояння свавіллю представників державної влади і в такій ролі є механізмом контролю за адміністрацією, обмежують усевладність держави. 3 іншого боку, вони (за умов їх дотримання) дають змогу подолати відчуження влади від народу за допомогою широкого залучення населення до формування та участі в діяльності держави й інших політичних структур» $[9$, с. 61$]$.

Водночас обмеження влади держави правами людини не має вести до приниження iï ролі. Держава мусить всіма способами сприяти найбільш повному здійсненню прав людини й водночас не перевищувати міру розумного, щоб не втручатися в особисте життя людей і не обмежувати їхніх прав і свобод. У правах людини має бути встановлений той баланс, який, з одного боку, відкриває особі можливості безперешкодно розвивати свій творчий хист і проявляти творчий потенціал, а з іншого визнаватися і поважатися загальнодержавні цілі, те, що об’єднує всіх, оскільки особа і держава - «супідрядні самоцілі» [18, с. 542]. Поль Валері свого часу зауважив, що «якщо держава сильна, вона нас придушує, якщо ж слабка - ми гинемо» $[19$, с. 6$]$. Справді, слабка законодавча, виконавча і судова влада робить людину беззахисною перед різного роду сваволею і беззаконням. Водночас варто враховувати, що права людини стають усе більшою реальністю, оскільки вони «зв'язують» державу, встановлюють для діяльності державних органів дозвільний порядок, визначений Конституцією. Тільки тоді, коли право і права людини стають над державою і нав'язують державі свої настановлення, зумовлені розвитком культури і цивілізації, держава також стає цивілізованою» [5, с. 58-59].

Не підлягає сумніву, що головна роль у гарантії прав і свобод належить державі. Саме вона відповідно до чітко вираженого волевиявлення багатонаціонального народу в формі референдуму з урахуванням загальновизнаних принципів i норм міжнародного права закріплює і захищає права і свободи людини і громадянина.

Сучасні дослідники, також виступаючи проти диктату влади в питаннях певного обсягу і характеру наданих людині прав і свобод, роблять акцент на взаємності відповідальності людини і держави за гарантованість і використання прав.

Беручи на себе зобов'язання щодо забезпечення свободи особистості, держава має право вимагати від громадян правомірної поведінки, яка відпо- відала б стандартам, зафіксованим в юридичних нормах. Без організованості та дисципліни, без узгодження поведінки громадян з юридичними приписами, що виражають державну волю, неможливо вирішити найважливіші історичні, політичні завдання. Тому суспільство через систему органів держави формулює свої вимоги до громадян у системі обов'язків, встановлює заходи юридичної відповідальності за їх невиконання. Держава як носій політичної влади має в своєму розпорядженні спеціальні механізми забезпечення прав і свобод громадян та виконання ними своїх обов'язків. Більш пильне дослідження політико-правових основ зв'язків особистості і держави пояснюється, безсумнівно, тим, що право є основою і змістом відносин держави і особи. Однак чимале місце в цих відносинах займає моральність, моральні норми. Це при всьому тому, що в сучасній українській політико-правовій дійсності окремі політики і держава в практиці своїх взаємин нерідко виходять за межі правового простору. Розглядаючи сутність відносин особистості в суспільстві, необхідно досліджувати їх через розвиток і здійснення прав і обов'язків. Загальновідомо, що немає прав без обов'язків, як немає обов'язків без прав, - це аксіома юриспруденції. Принцип взаємної відповідальності держави й особистості, виражений у правовому статусі, найпереконливіше розкриває особливість становища особистості в демократичному суспільстві, реальність і гарантованість її прав [3, с. 21].

Демократична держава бере на себе відповідальність за правильне, науково обгрунтоване закріплення в законодавстві того обсягу свободи особистості, який відповідає досягнутому етапу суспільного розвитку, що дає змогу створити відповідну систему гарантій, покликану реалізувати права і свободи громадян, що передбачає в цих цілях державний механізм з відновлення порушеного права і застосування санкцій до осіб, винних у порушенні своїх обов'язків. Якби свободі особистості не відповідали обов'язки держави, їі соціальна відповідальність, то ці права і свободи носили б лише декларативний характер. Взаємна відповідальність держави і суспільства, а також особистості і держави, суспільства і особистості це найважливіший гуманістичний і демократичний принцип побудови демократичної правової держави. Такої ж точки зору дотримується більшість авторів [20, с. 19].

У сучасному суспільстві індивідуалізація прав і свобод особистості починає панувати над особливими правами держави, нав'язуючи агресивне розуміння прав людини на шкоду прав суспільства. Про ці можливі проблеми писав ще англійський філософ Е. Берк, підкреслюючи, що громадянське суспільство було створено для блага людини, отже, вона має право на всі переваги, якими це суспільство володіє, тобто люди мають право 
на справедливість, на заняття політичних посад у державі, на власність і успадкування майна батьків. I в цьому партнерстві у всіх людей є рівні права, але не рівне майно. «Що ж стосується прав на розподіл влади, керівництво державними справами, я завжди буду стверджувати, що вони лише формально входять у число прямих і основних прав людини в громадянському суспільстві» [21, с. 70]. Тобто, щоб зберегти свободу, люди мають довірити іiі державі. Становище людини в демократичній державі характеризується високим ступенем організованості суспільства, його активною політичною позицією, умінням відстоювати свої життєво важливі інтереси, гармонійно взаємодіючи 3 державою. Домінуючий вплив особистості у взаємозв' язках з державою визначається тим, що особистість є провідним елементом громадянського суспільства і політичної системи. Водночас взаємини, зв'язки особистості і держави здійснюються в межах їх правових основ.

Важливим засобом здійснення і захисту прав і свобод громадян, зміцнення зв'язків населення 3 державним апаратом $є$ передбачене статтею 40 Конституції право направляти індивідуальні чи колективні письмові звернення або особисто звертатися до органів державної влади, органів місцевого самоврядування та посадових і службових осіб цих органів, що зобов'язані розглянути звернення і дати обгрунтовану відповідь у встановлений законом строк. Отже, у демократичній державі громадяни виступають як активна, ініціативна сила, що спонукає державу на реформаторські дії і попереджає помилки і зловживання влади.

Реалізація прав людини - це необхідна умова нормального розвитку політичних процесів у суспільстві, функціонування демократичних інститутів, формування громадянського суспільства, забезпечення політичної та соціальної рівноваги в суспільстві. Перехід від тоталітарної держави до демократичної і правової, в якій вищою цінністю $€$ людина, її життя, права й свободи - це складний і тривалий процес. В основі всіх політичних і соціально-економічних перетворень у суспільстві має бути вища мета - забезпечення прав і свобод людини. А. Стичинська слушно зазначила, що демократизація політичної системи є умовою реалізації громадянських та політичних прав людини [22].

Отже, держава, будучи основною формою консолідації громадян, суспільства, цінностей, створює умови для розвитку особистості, можливості реалізації її прав і свобод, і особистість, все це отримуючи, несе відповідальність перед співгромадянами, державою, тобто існує взаємовідповідальність, взаємозумовленість, у разі порушення якої вірогідний правовий хаос, що веде до зростання злочинності і тиранії держави. Права людини мають визнаватися й охоронятися суспільством і державою, і саме це має бути реаль- ним фактором відносин між особою і державою, заснованих на принципі свободи та взаємної відповідальності, на нормах права і моралі. Тільки взаємна відповідальність держави й особи, взаємна відповідальність співгромадян створюють той політичний і морально-психологічний клімат, за якого забезпечується справжня гідність кожної особи, її права та інтереси. Держава має взяти на себе зобов' язання забезпечити їх охорону і захист через систему законодавчих заходів.

\section{Jimepamypa}

1. Конституція України : прийнята на п'ятій сесії Верховної Ради України 28.06.1996 p. URL: http://zakon3.rada.gov.ua/laws/show/254\% D0\% BA/ 96- $\%$ D0 $\%$ B $2 \%$ D $1 \%$.

2. Права человека / отв. ред. Е.А. Лукашева. Москва : НОРМА, 2003. 573 с.

3. Басик В.П. Эволюция правового статуса личности и его отражение в правовой науке. Правоведение. 2005. № 1. C. 21-35.

4. Права человека : Энциклопедический словарь / отв. ред. С.С. Алексеев. Москва : Норма, 2009. 656 с.

5. Права человека : учебное пособие / А.Д. Гусев, Я.С. Яскевич, Ю.Ю. Гафарова и др.; Под общ. ред. А.Д. Гусева и Я.С. Яскевич. Минск : «ТетраСистемс», 2002. $304 \mathrm{c}$.

6. Бережнов А.Г. Политика и права человека. Политология. Курс лекций / Под ред. М.Н. Марченко. Москва : Наука, 1993. С. 172-182.

7. Хеффе О. Политика. Право. Справедливость. Основоположения критической философии права и государства / пер. с нем. В.С. Малахова при участии Е.В. Малаховой. Москва : Гнозис, 1994.328 с.

8. Общая теория прав человека / руководитель авторского коллектива и отв. ред. д.ю.н. Е.А. Лукашева. Москва : Норма, 1996. 520 с.

9. Шукліна Н.Г. Конституційно-правове регулювання прав і свобод людини і громадянина в Україні (проблема теорії та практики) : монографія. Київ : Центр навчальної літератури, 2005. 424 с.

10. Чепульченко Т.О. Правова держава як гарант дотримання основних демократичних принципів та правлюдиниусуспільстві.URL:http://www.ccf.org.ua/ for-social-workers-article.

11. Лукашева Е.А. Кризисная ситуация в советском обществе и права человека. Права человека: время трудных решений. Москва, 1991. $176 \mathrm{c}$.

12. Мороз Е. Понятие прав человека с точки зрения нормативно-ценностного подхода. Пробель в российском законодательстве. 2011. № 2. С. 23-27.

13. Права людини. Міжнародні договори України, декларації, документи / упоряд. Ю.К. Качуренко. Київ : Наук. думка, 1992. 200 с.

14. Международные акты о правах человека : сборник документов. Москва : НОРМА-ИНФРА, 2000. $784 \mathrm{c}$.

15. Витрук Н.В. Общая теория правового положения личности. Москва : Норма, 2008. 448 с.

16. Зорькин В.Д. Конституция и права человека в XXI веке. К 15-летию Конституции Российской Федерации и 60-летию Всеобщей декларации прав человека. Москва : Норма, 2008. 224 с.

17. Права человека : учебник для вузов. / Ответственный редактор - член-корр. РАН, доктор юридических наук Е.А. Лукашева. Москва : Издательская группа НОРМА - ИНФРА-М, 1999. 573 с. 
18. Кистяковский Б.А. Философия и социология права / Сост., примеч., указ. В.В. Сапова. Санкт-Петербург : РХГИ, 1999. 800 с. (Русская социология XX века).

19. Люшер $\Phi$. Конституционная защита прав и свобод личности. Издательская группа «Прогресс»«Универс», 1993. 384 с. (пер. с франц.).

20. Азми Д.М. Теория структурного строения системы права: традиции и новации. Гражданин и право. Москва : Новая правовая культура. 2011. № 7. С. 15-21.

21. Бёрк Э. Размышления о революции во Франции. Москва : «Рудомино», 1993. 144 с. URL: https://www.gumer.info/bibliotek_Buks/History/ Article/berk_razm.php.

22. Стичинська А. Співвідношення політики і прав людини. Український науковий журнал «Ocвiта регіону: політологія, психологія, комунікації». URL: http://social-science.com.ua/article/1091.

\section{Анотація}

Марущак Н. В. Щодо політичного аспекту прав людини. - Стаття.

У статті аналізуються права людини як політико-правова категорія, розглядаються наукові підходи до проблеми співвідношення інтересів особи і держави, роль держави в додержанні прав та свобод людини та перспективи їх розвитку в сучасному суспільстві.

Центральною проблемою сучасного суспільства є вироблення і забезпечення нових юридичних норм у сфері прав людини. Права людини як універсальна цінність визначають межі свободи політики, політиків та державної влади. Права людини окреслюють межі діяльності держави, визначають спрямованість державноі політики. Права встановлюють чіткі правила, на яких будуються взаємини між особою і державою, розвиваються принципи автономії або співпраці, взаємної відповідальності. Водночас обмеження влади держави правами людини не має вести до приниження іï ролі. В процесі дослідження автор доходить висновків, що держава, будучи основною формою консолідації громадян, суспільства, цінностей, створює умови для розвитку особистості, можливості реалізації ї̈ прав і свобод, і особистість, все це отримуючи, несе відповідальність перед співгромадянами, державою, тобто існує взаємовідповідальність, взаємозумовленість, у разі порушення якої вірогідний правовий хаос, що веде до зростання злочинності і тиранії держави. Права людини мають визнаватися й охоронятися суспільством і державою, i саме це має бути реальним фактором відносин між особою і державою, заснованих на принципі свободи та взаємної відповідальності, на нормах права і моралі. Тільки взаємна відповідальність держави й особи, взаємна відповідальність співгромадян створюють той політичний і морально-психологічний клімат, за якого забезпечується справжня гідність кожної особи, її права та інтереси.

Ключові слова: права людини, держава, взаємна відповідальність, державна політика у сфері прав людини, демократія.

\section{Summary}

Marushchak N.V. On the political aspects of human rights. - Article.

The article analyzes human rights as a political and legal category, examines scientific approaches to the problem of the relationship of interests of the individual and the state, the role of the state in the observance of human rights and freedoms and prospects for their development in modern society.

The central problem of modern society is the development and provision of new legal norms in the field of human rights. Human rights as a universal value define the boundaries of freedom of politics, politicians and state power. Human rights delineate the boundaries of state activity, determine the direction of state policy. The rights establish clear rules on which the relationship between the individual and the state is based, the principles of autonomy or cooperation and mutual responsibility are developed. At the same time, limiting the power of the state to human rights should not diminish its role. In the course of the study, the author comes to the conclusion that the state, being the main form of consolidation of citizens, society, values, creates conditions for the development of the individual, the possibility of realizing its rights and freedoms, and the individual, all this receiving, is responsible to fellow citizens, the state, that is, there is mutual responsibility, interdependence, in violation of which is likely legal chaos, which leads to an increase in crime and tyranny of the state. Human rights should be recognized and protected by society and the state, and this should be a real factor in the relationship between the individual and the state, based on the principle of freedom and mutual responsibility, on the norms of law and morality. Only the mutual responsibility of the state and the individual, the mutual responsibility of fellow citizens create the political, moral and psychological climate in which the real dignity of each individual, his rights and interests are ensured.

Key words: human rights, state, mutual responsibility, state policy in the field of human rights, democracy. 